\title{
Significance of co-digestion as energy recovery at a sewage treatment plant amenable to a shrinking population
}

\author{
Akihiko Terada ${ }^{1}$ \\ Published online: 4 June 2018 \\ ๑) Springer-Verlag GmbH Germany, part of Springer Nature 2018
}

The world population has been inevitably increasing. The excessive population growth is a big wake-up call for researches on food science, environmental science/engineering and sustainability. We are required to bear a mission to make our planet sustainable. That being said, there are countries, however, where the populations are decreasing. According to the investigation by World Population Prospects: The 2017 Revision (United Nations 2017), there are 51 countries $^{1}$ where the populations will decrease from 2017 to 2050 . One of the countries facing shrinking population is Japan. It had the highest population of 128.08 million in 2008 (Ministry of Land, Infrastructure, Transport and Tourism (MLIT) Japan 2015), which has been gradually decreasing and is projected to end up with the decline down to 109 million in $2050,15 \%$ decrease from 2009 (United Nations 2017). The country is entering an era of "super-aged" society as defined by the WHO because of a low fertility rate and extension of life expectancy.

Taking a look at the situation more closely on population of Japan, population concentration and depopulation are ongoing at the same time. According to the population statistics announced by Statistics Bureau in the Ministry of Internal Affairs and Communications of Japan (http://www.stat.go.jp/ english/data/jinsui/2017np/index.html), 40 out of 47 prefectural and city governments are further experiencing sparser population as of October 1, 2017, although the reminders including Tokyo Metropolitan are experiencing denser population. Given these contrastive situations, how are municipal wastewater treatment facilities affected? In developed countries, sewerage infrastructure was developed decades ago. In case of an increase in residences, the amount of municipal wastewater flowing into a treatment facility increases, which

All URLs in this editorial were viewed on May 29, 2018.

Akihiko Terada

akte@cc.tuat.ac.jp

1 Department of Chemical Engineering, Tokyo University

of Agriculture and Technology, 2-24-16 Naka,

Koganei, Tokyo 184-8588, Japan potentially makes physical and biological units in the facility overloaded. In order to permanently comply with stringent effluent standard, a main challenge is retrofitting a biological unit to improve removal performances of carbon, nitrogen and phosphorus without extending the area of biological units. Given the significance of cost reduction and energy/ resource recovery as an emergent issue, of importance is development and implementation of novel biological processes, e.g., anaerobic ammonium oxidation as cost-effective nitrogen removal (Lackner et al. 2014), anaerobic membrane bioreactors for rapid recovery of methane in a mainstream of municipal wastewater treatment and nutrient recovery units (Li et al. 2015).

On the other hand, a municipality experiencing depopulation conversely provides a distinct situation where the amount of receiving wastewater is reduced. What could this situation affect municipalities responsible for wastewater treatment? Whereas an economic situation in these municipalities would be tight due to decrease in revenue, decrease in the amount of wastewater may provide a new opportunity where a wastewater treatment facility can function as a site for resource recovery and energy harvesting, given the report by MLIT Japan in 2007 (http://www.mlit.go.jp/crd/sewer age/mifukyu/02/pdf/200606-02.pdf (in Japanese)).

Implementation of co-digestion, i.e., anaerobic digestion by mixing excess and primary sludge in a wastewater treatment facility with external biomasses, could be one of the promising ways. The biomasses could be food wastes, rice straws, riverbank plants, night soils, livestock manure and so on. Choice of these biomasses will depend on their accessibilities and local conditions of municipalities. MLIT takes the initiative of supporting municipalities toward a strategy that a local wastewater treatment facility becomes a "biomass station" (http://www.mlit.go.jp/common/001197678. pdf (in Japanese)) accepting locally external biomasses. The concept underlies the situation where a wastewater treatment

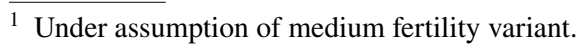


facility takes advantages of an unused space due to decrease in receiving wastewater. To consolidate the implementation of the concept, MLIT starts dispatching specialized staffs to give advice on available biomasses, to summarize challenges and to show economic feasibility according to the recent press release on May 10, 2018 (http://www.mlit.go.jp/repor t/press/mizukokudo13_hh_000373.html (in Japanese)). This campaign would expectedly bring model cases where locally available and various biomasses are co-digested with excess sludge to yield more methane.

Since biomasses have different compositions, the properties of methane production would differ, which warrants future thorough investigation. The current issue is entitled "Sustainable Bioenergy Systems: Supply chains, Processes \& Products" dealing with conversion of biomass to bioethanol, biofuel production and ammonia recovery from digestate. These articles provide potential clues allowing transformation of a wastewater treatment facility into an energy-harvesting facility and/or a factory for valuable products. This transformation could be a big paradigm shift that chemical and environmental engineering will have to confront. In order to make it feasible in the near future, multidisciplinary approaches would be important as previously claimed (Nghiem et al. 2017). Local population shrinkage in developed countries slowly but surely comes. From the standpoint of energy autarky of a community, we need to think of a way to better utilize the current wastewater treatment facilities.

\section{References}

Lackner S, Gilbert EM, Vlaeminck SE, Joss A, Horn H, van Loosdrecht MCM (2014) Full-scale partial nitritation/anammox experiences-an application survey. Water Res 55:292-303

Li WW, Yu HQ, Rittmann BE (2015) Chemistry: reuse water pollutants. Nature 528(7580):29-31

Ministry of Land, Infrastructure, Transport and Tourism Japan (2015) Current conditions in Japan such as declining population. White Paper on Land, Infrastructure, Transport and Tourism in Japan 2014

Nghiem LD, Koch K, Bolzonella D, Drewes JE (2017) Full scale codigestion of wastewater sludge and food waste: Bottlenecks and possibilities. Renew Sustain Energy Rev 72:354-362

United Nations, Department of Economic and Social Affairs, Population Division (2017) World Population Prospects: The 2017 Revision, DVD Edition 